\title{
Attributes of 3D Computer Models for Learning the Structure of Atom by Undergraduate Science Teacher's Students
}

\author{
Dr. Mustafa Akıllı \\ Bursa Uludag University, Faculty of Education, Turkey
}

Doi:10.19044/ejes.v8.no2a85

URL:http://dx.doi.org/10.19044/ejes.v8no2a85

Submitted: 03 May 2021

Copyright 2021 Author(s)

Accepted: 08 June 2021

Under Creative Commons BY-NC-ND

Published: 30 June 2021 4.0 OPEN ACCESS

\begin{abstract}
This paper focuses on examining the effectiveness of three-dimensional (3D) computer models on student teachers' academic achievement, mental model construction, and spatial ability used in learning the "atomic models" topic in this study. The students were randomly assigned into two groups: the treatment group (TG) where 3D computer models were used and the control group (CG) where models were not used for teaching. The treatment group was instructed using 3D computer models, while the traditional learning process was adopted in the control group. With the help of SPSS software, the independent-groups t-test and one way MANOVA were performed between the control and treatment groups. Cohen's d and eta-squared values were calculated for the effects of the computer models. Through this study, it was seen that the instruction using 3D computer models contributed to students' achievement, mental model construction, and spatial ability more than the traditional instructional process.
\end{abstract}

Keywords: 3D computer models, atomic models, modelling, spatial ability, mental models

\section{Introduction}

A model is a representation of an object, a process or a system which is commonly used in science (Gilbert \& Boulter, 1998). Models are constructed when an object or a phenomenon is too small, too large, too complex, too distant or inaccessible (Valanides \& Angeli, 2008). Models and modelling are important in science because they play an important role in technology and the nature of science (Bekiroglu Ogan, 2006). Based on the different researches cited from Krell, Upmeier zu Belzen, and Krüger (2014), their importance in scientific communication and reasoning is well known.

Models can be classified into two types which are mental (internal) and expressed(external) models (Gobert \& Buckley, 2000). Mental or internal models refer to individuals' representation of their explanatory mechanisms, while expressed or external models are the external representations of internal models. Expressed models can be diagrammatic, physical or computational models (Kim \& Lee, 2013) such as 3D computer models, simulations or animations. Learning environments with computer models in science education started years ago while using some computer software, which was studied in several researches (Chen, Hsiao, \& She, 2015). Computer modeling has been stated as a useful instructional tool which can be used to encourage students in the design of scientific models for describing, explaining, and predicting scientific 
phenomena (Jara, Esquembre, Christian, Candelas, Torres, \& Dormido, 2012). They are also seen as a key process for teaching and learning science (Acher, Arca, \& Sanmarti, 2007), effective pedagogical tools for teaching (Halloun, 2007), and playing a central role in the justification and formation of knowledge in science education (Koponen, 2007). There are also other studies that recognize the importance of models in science education (e.g., Gilbert \& Boulter, 1998; Gobert \& Buckley, 2000; Justi \& Gilbert, 2000).

Students have significant difficulties when learning science (Rutten, van Joolingen, \& van der Veen, 2012) because many science concepts are invisible and abstract for students. As a result, students often create numerous alternative or inappropriate conceptions and models in their minds (Chen et al., 2015). Some studies have suggested several possible solutions to overcome these hard situations such as integrating some visualization tools (Barak \& Hussein-Farraj, 2013) which are important for better understanding (Habraken, 1996) and communication (Ametller \& Pinto, 2002) among students about science concepts. This helps them get the knowledge that they may not obtain from verbal explanations alone (Patrick, Carter, \& Wiebe, 2005). 3D computer models enhance visual explanations of scientific phenomena that are not directly observable (Gobert, 2000) and provide a meaningful learning experience to make connections between observable phenomena and targeted concepts (Kim \& Lee, 2013). For science, integrating computer models in instructional contexts may provide new or different opportunities to students to improve their understanding of unobservable phenomena (Barak, Ashkar, \& Dori, 2011; Gilbert 2005; Zhang, Liu, \& Krajcik, 2006), and to make abstract concepts visible (Barak \& Hussein-Farraj, 2013).

\section{Learning and $3 D$ Computer Models}

Why is learning with 3D computer models effective? Reasons for better learning with 3D models can be explained by Mayer's cognitive theory of multimedia learning. According to Mayer (2003), multimedia learning recognizes when students construct mental representations from words and pictures presented to them, and they can learn more from multimedia messages than from more traditional modes of presentation involving words only. This theory is based on three presumptions: (i) the dual channel presumption, (ii) the limited capacity presumption, and (iii) the active processing presumption (Mayer \& Moreno, 2002). The dual channel assumption of Mayer uses the dual coding theory of Paivio which suggests teaching students about a system using both verbal and nonverbal codes (Moreno \& Valdez, 2005). Mayer's assumption states that the presentation and processing of information in humans is cognitively cared for by two independent sub-systems: one concerned with verbal, and the other concerned with non-verbal (visual) materials. Thus, this assumption supports a dual coding hypothesis. Also, the limited capacity assumption is compatible with Baddeley's working memory model and Sweller's cognitive load theory (Paas, Tuovinen, Tabbers, \& Van Gerven, 2003). The limited capacity presumption states that each working memory channel can build only a limited amount of visual or verbal information at any time (Mayer \& Moreno, 2003). More so, the active processing assumption of Mayer stated that students note the relevant information, organize them by selection and exchange selected information into coherent mental representations, and integrate these mental representations into prior knowledge (Urhahne, Nick, \& Schanze, 2009). According to this presumption, meaningful learning involves significant conscious processing within the verbal and visual channels (Moreno \& Valdez, 2005).

The "learning by modelling" role of models in science education is highlighted by Gobert, O’Dwyer, Horwitz, Buckley, Levy, and Wilensky (2011). Krell, Reinisch, and Kruger (2015) have also cited the increasing value of using models to learn scientific content knowledge. As a type of models, the use of 3D computer visualization models in the science classroom has big potential to produce higher learning outcomes in ways not previously possible (Akpan, 2001). In their article, 
Rutten et al. (2012) reviewed the researches about the learning effects of computers in science education. They reported that computers had improved better understandings, more knowledge expansions, and higher learning outcomes. Similarly, Chen et al. (2015) cited that many studies have suggested that multimedia tools or software enable students to overcome the difficulty of learning successfully and thus help students to achieve better learning outcomes. This study intended to explore if students' achievement performance in the atomic models topic after learning with 3D computer models are different from students who learn in the traditional learning process where teachers use only static $2 \mathrm{D}$ pictures, figures, etc.

\section{Mental Models and 3D Computer Models}

One of the definitions of mental models was made by Johnson-Laird in 1983 that "a mental model is a type of dynamic representation that people use to present the world in order to understand a body of knowledge, predict the development of the world, and generate follow up actions". Norman in 1983 also stated that "a mental model is an interactive product that people form as a result of the interactions between the environment, people, and the artifacts of technology" (cited in Chen et al., 2015, p.171). In the years that followed, Franco and Colinvaux (2000) stated that mental models are people's internal representations of real situations in their minds which they use for understanding and perceiving what happens. It can therefore be said that mental models are a form of an individual's knowledge representations about their environment. Mental models are cognitive representations (Buckley \& Boulter, 2000) that are personal and private (Gobert 2000), unscientific, incomplete and unstable (Greca \& Moreira, 2000), and unique to the observer (Coll \& Treagust, 2002). The main role of mental models is to allow their builder to explain and make predictions about the system represented by it (Greca \& Moreira, 2000). They are constructed by learners and scientists to interpret their experiences and to make sense of the physical world (Coll \& Treagust, 2002). They also interpret the result when people face specific situations in order to solve problems and create new concepts (Vasniadou \& Brewer, 1992).

According to Greca and Moreira (2000), the idea behind computer models is that mental models can be considered as 'mental simulation' of the real situation of the problem and as 'feasible' causal models for the system or mechanism they represent. Therefore, this study aims to explore the effectiveness of 3D computer models with respect to students' mental model construction.

\section{Spatial Ability and 3D Computer Models}

Spatial ability is defined as the capacity to generate, retain, retrieve, and transform wellstructured visual images (Lohman, 1993), and it involves representing, rotating, and inverting objects in three dimensions when they are presented in two dimensions (Barnea, 2000). Spatial ability is the capacity to imagine changes which have occurred after folding or rotating the two or three dimensional objects. It comes into prominence when rotating objects, visualizing images or arranging pieces of an entire system in a suitable way (ChanLin, 2000; Hartman, Connolly, Gilger, \& Bertoline, 2006; Orde, 1997). According to Hartman et al. (2006), many tasks in our world require the ability to perform spatially. Without spatial ability, success within specific disciplines such as science, engineering, the arts, etc. can be limited. Similarly, Black (2005) stated that spatial ability is a cognitive factor that is linked to high performance in science. Since science is an abstract area, Orde (1997) stated that spatial skills have brain functions for the processing of information which enable the conversation of an abstract visualization to a concrete product. As mentioned above for science learning, it seems that 3D computer models are important constructs. 
Hartman et al. (2006) also stated that in some situations, it may be possible to improve the spatial ability of students. This study thus aims to investigate if $3 \mathrm{D}$ computer models are able to impact students' spatial ability.

\section{Purpose}

The purpose of this study was to determine the effectiveness of 3D computer models, used in the atomic models topic in the Introduction to Modern Physics course, on first year science teacher candidates' achievement, mental models, and spatial ability before and after the teaching and learning process. The study aimed to answer the following research questions:

Research Question 1: Is there any significant difference in students' achievement between a learning environment supported by 3D computer models and a traditional learning environment in the topic of atomic models?

Research Question 2: Is there any significant difference in students' mental models between a learning environment supported by 3D computer models and a traditional learning environment in the topic of atomic models?

Research Question 3: Is there any significant difference in students' spatial ability between a learning environment supported by 3D computer models and a traditional learning environment in the topic of atomic models?

\section{Methodology of Research \\ Participants and Procedure}

Sixty-one second-year undergraduate (science teacher candidate) students from two classes of the "Introduction to Modern Physics" course, taught by the researcher, participated in this study. The students were randomly assigned into two groups: treatment group (TG) where 3D computer models were used and the control group (CG) where models were not used for teaching. The CG was taught the atomic models topic using 2D graphics, pictures, figures, etc. from textbooks in a teacher centered approach using talk-and-chalk type lessons, while the TG was taught using 3D computer models for two weeks. The pre-tests for achievement and spatial ability were given to students of both the control and treatment groups before they were taught the topic of atomic models. The post-tests for achievement, spatial ability, and mental models were given immediately to both control group and treatment group students after they finished two weeks of learning. The framework of the teaching and learning process involved in this study is summarized in Figure 1. 


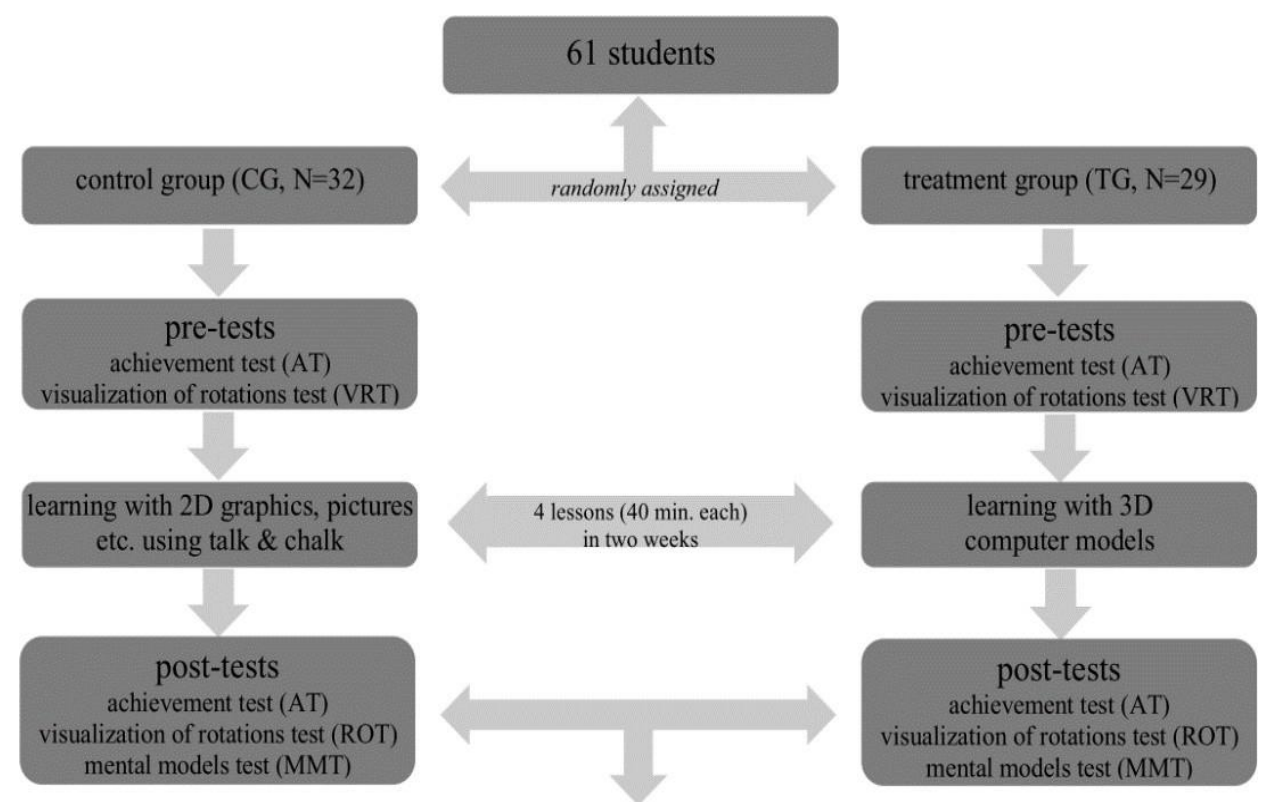

Figure 1. The framework of the study

\section{Design of 3D Computer Models}

The 3D computer models used in the treatment group for teaching were prepared using the 3D Studio Max 9 program in order to describe atomic models. This program is a professional 3D modeling, animation, and rendering software used mostly by design visualization specialists, game developers or visual effects artist. The models could also be thought of as a different type of animation films. Some properties of models used in instruction are given in Table 1.

Table 1. Properties of 3D computer models

\begin{tabular}{|c|c|c|c|}
\hline Models & Subject & Purpose & $\begin{array}{l}\text { tim } \\
\text { e } \\
(\mathrm{s})\end{array}$ \\
\hline Model 1 & $\begin{array}{l}\text { Thomson's atomic } \\
\text { model }\end{array}$ & To explain Thomson's atomic model and theory & 91 \\
\hline \multirow{3}{*}{$\begin{array}{l}\text { Model 2- } \\
3-4\end{array}$} & \multirow{3}{*}{$\begin{array}{l}\text { Rutherford's } \\
\text { model }\end{array}$} & $\begin{array}{l}\text { To explain Rutherford's experiment (materials, } \\
\text { process and results) }\end{array}$ & \multirow{3}{*}{$\begin{array}{l}178 \\
76 \\
91\end{array}$} \\
\hline & & $\begin{array}{l}\text { To explain Rutherford's atomic model and } \\
\text { theory }\end{array}$ & \\
\hline & & $\begin{array}{l}\text { To explain Rutherford's atomic model } \\
\text { drawbacks }\end{array}$ & \\
\hline Model 5-6 & & To explain $1^{\text {st }}$ postulate of Bohr's atomic model & 90 \\
\hline Mioder J-0 & Bohr's atomic model & To explain $2^{\text {nd }}$ postulate of Bohr's atomic model & 90 \\
\hline Model 7-8 & Energy levels in atom & $\begin{array}{l}\text { To explain atomic excitation } \\
\text { To explain relaxation back to the ground state of } \\
\text { an atom }\end{array}$ & $\begin{array}{l}85 \\
100\end{array}$ \\
\hline
\end{tabular}

Some examples from the 3D computer models used for teaching in the treatment group are 
given below (Figure 2).
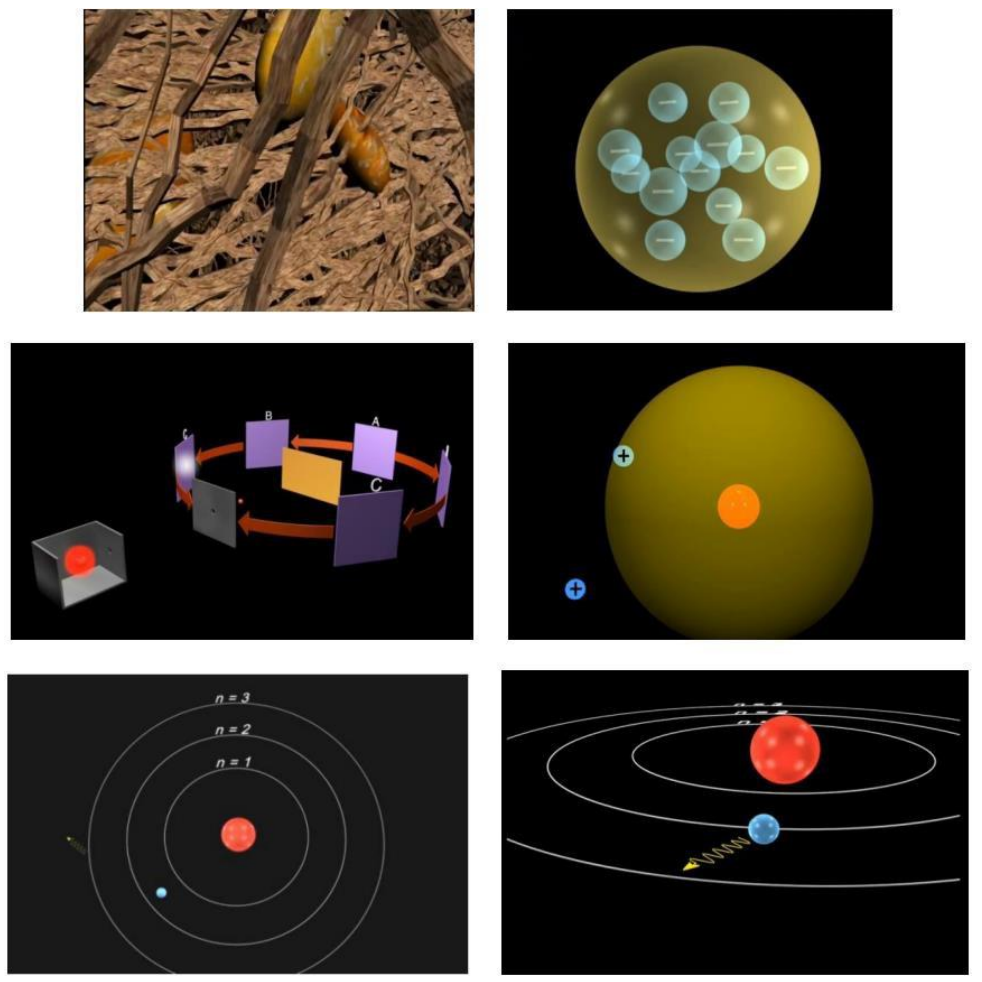

Figure 2. Screenshots from 3D computer models

The achievement test (AT), developed by a panel of six experts (including the researcher, one science education researcher, three physics education researchers, and one chemistry education researcher), was used to determine students' achievement in the atomic models unit and to observe if there was a significant difference between the two groups. The AT is a multiplechoice test which consisted of 20 questions. Every question had five responses and a value for one point was awarded for a correct answer. Therefore, the test gives continuous scale scores ranging from 0 to 20 . The Cronbach's $\alpha$ value was 0.72 , thus the achievement test had satisfactory statistical reliability.

\section{Mental Model Test}

The mental model test (MMT) was developed to examine the accuracy of students' mental models and their construction of atomic models after instruction with 3D computer models. The same panel was involved in the process of designing the test. Five open-ended mental model construction questions related to Thomson's atomic model, Rutherford's experiment and its results, and Bohr's atomic model and his postulates were developed which required students to draw their mental models and provide explanations. For the MMT, the students' drawings and explanations in each item were analyzed. Scores from 0 to 2.0 was awarded for their wrong drawings and/or wrong explanations, 1 point was given for partial drawings and/or partial explanations, and 2 points was awarded for correct drawings and/or explanations. Thus, there was a total of 20 points for the MMT with a maximum possible score of 10 points for drawings and 10 points for explanations. 


\section{Purdue Visualization of Rotations Test}

The Purdue visualization of rotations (ROT) test, one element of the Purdue Spatial Visualization Test Battery, was developed to measure students' spatial ability in terms of rotating 3D objects. ROT, which consisted of 20 items, was developed by Bodner and Guay (1997). The Kuder-Richardson (KR-20) reliability of the ROT test was found to be 0.80 . This data suggested that the ROT test was internally consistent. An example of an item in the ROT test is given below (Bodner, 1976) in Figure 3:
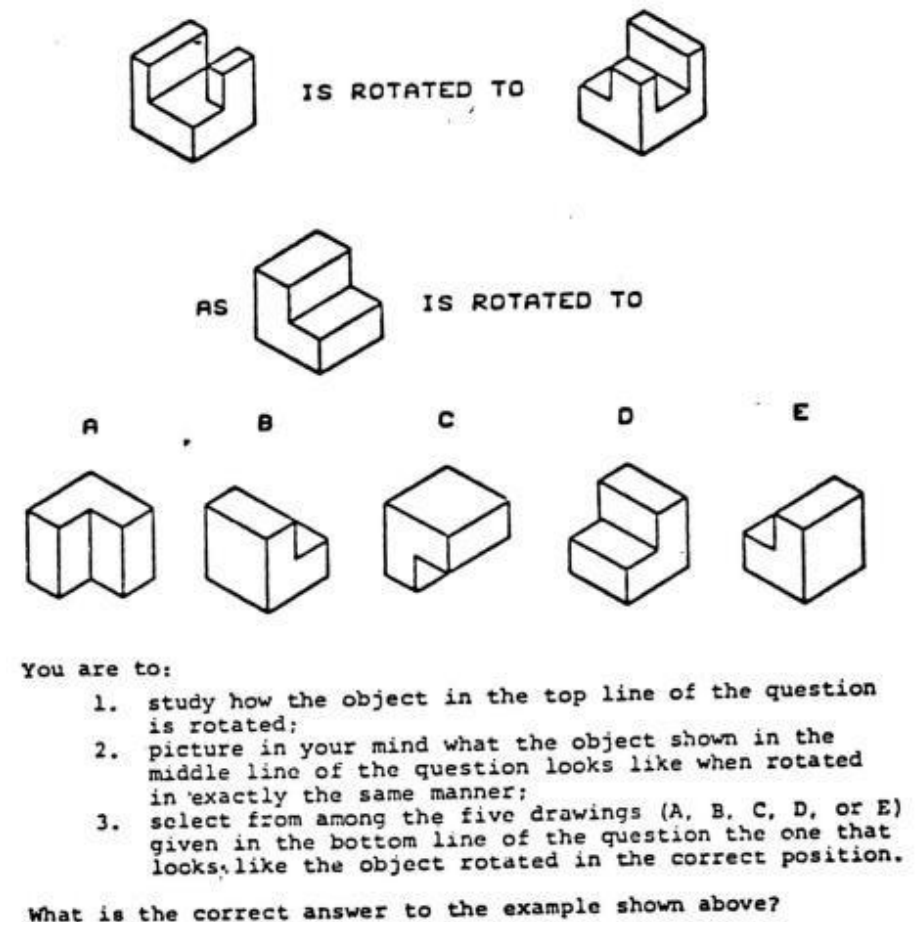

Figure 3. Directions and an example of ROT

\section{Results of Research}

\section{Analysis of Achievement Test}

Descriptive statistics and independent samples $T$ test were employed to investigate if treatment group students made progress on their atomic models topic before and after learning. This was supported by 3D computer models in comparison with the control group. Analysis showed that there was no statistically significant difference between the groups in the pre-test $\left(T_{(59)}\right.$ $=0.52, p>.05)$. However, the TG students who learned the atomic models topic with $3 \mathrm{D}$ computer models made statistically significant differences in the post-test $\left(T_{(59)}=5.95, p<.05\right)$

Table 2. The results of the achievement test

\begin{tabular}{lllllllll}
\hline & \multicolumn{1}{l}{ Pre-test } & \multicolumn{7}{c}{ Post-test } \\
\cline { 2 - 9 } & $N$ & Mean & SD & t-value & $N$ & Mean & SD & t-value \\
\hline CG & 32 & 6.47 & 2.34 & \multirow{2}{*}{0.52} & 32 & 12.88 & 2.15 & \multirow{2}{*}{$5.95^{*}$} \\
TG & 29 & 6.14 & 2.61 & & 29 & 15.66 & 1.37 & \\
\hline
\end{tabular}

$* \mathrm{p}<.05$

Cohen's $d$ was also calculated for the effect size of 3D computer models in this process. The 
Cohen's $d$ of the TG students in the achievement test in comparison to the CG students was found to be 1.54 .

\section{Analysis of Mental Models Test}

After two weeks of the learning and teaching process, the MMT was administered to both students in the TG and the CG. As shown in Table 3, students in the TG had better scores than the students in the CG.

Table 3. The results of mental models test

\begin{tabular}{llllllll}
\hline & & \multicolumn{2}{c}{ MMT-drawing } & \multicolumn{2}{l}{$\begin{array}{l}\text { MMT- } \\
\text { explanation }\end{array}$} & \multicolumn{2}{c}{ MMT-total } \\
\cline { 3 - 8 } & $\mathrm{N}$ & Mean & SD & Mean & SD & Mean & SD \\
\hline CG & 32 & 3.19 & 1.89 & 6.84 & 1.19 & 10.03 & 2.34 \\
TG & 29 & 7.76 & 1.38 & 7.21 & 1.74 & 14.97 & 2.57 \\
\hline
\end{tabular}

One way MANOVA was conducted to explore whether students' scores in the TG and the CG were statistically significant or not. It was found that Wilks' Lambda significance value was $.000\left(F_{2,58}=57.083, p<.05\right)$. Thus, there is a statistically significant difference between the CG and the TG for one or more dependent variable. As shown in Table 4, there was a statistically significant difference between the groups: MMT-drawing scores $\left(F_{1,59}=114.230, p<.05\right)$ and MMT-total scores $\left(F_{1,59}=61.397, p<.05\right)$. Also ${ }^{2}$ values were found to be .659 for MMT- drawing scores and .510 for MMT-total scores. Considering the mean scores in Table 3, it is clearthat these differences are in favor of the TG.

Table 4. One way MANOVA results of the mental model test

\begin{tabular}{|c|c|c|c|c|c|c|}
\hline $\begin{array}{l}\text { Depende } \\
\text { nt } \\
\text { variable }\end{array}$ & $\begin{array}{l}\text { Sum of } \\
\text { squares }\end{array}$ & $\mathrm{df}$ & $\begin{array}{l}\text { Mean } \\
\text { square }\end{array}$ & $F$ & $p$ & $\sqsubset^{2}$ \\
\hline $\begin{array}{l}\text { MMT- } \\
\text { drawing }\end{array}$ & 317.880 & 1 & 317.880 & 114.230 & $.000 *$ & .659 \\
\hline $\begin{array}{l}\text { MMT- } \\
\text { explanati } \\
\text { on }\end{array}$ & 2.006 & 1 & 2.006 & .918 & .342 & .015 \\
\hline $\begin{array}{l}\text { MMT- } \\
\text { total }\end{array}$ & 370.394 & 1 & 370.394 & 61.397 & $.000 *$ & .510 \\
\hline
\end{tabular}

\section{Analysis of Purdue Visualization of Rotations Test}

The descriptive statistics and independent samples $T$ test was employed to determine whether the 3D computer models helped the TG students' spatial ability in comparison with the CG. Analysis showed that there was no statistically significant difference between the groups in the pre-test $\left(T_{(59)}=0.176, p>.05\right)$. However, the TG students who were instructed in the atomic models topic with 3D computer models made statistically significant differences $\left(T_{(59)}=4.50, p<\right.$ .05) from the pre-test to the post-test compared to the students in the CG. As seen in Table 5, the ROT test scores of students in the TG increased approximately to $16.7 \%$. 
Cohen's $d$ was computed to determine the effect size. For the spatial ability performance of the TG students in comparison with the CG students, the effect of 3D computer models was found to be 1.16 according to the Cohen's $d$ test.

\section{Discussion and Conclusion}

This study examined if 3D computer models could help students develop their learning, mental model construction, and spatial ability in the atomic models topic. The study suggests a possible way to overcome difficulties about learning abstract topics in science specific to atomic models and opens a new avenue for students to construct true and complete mental models.

According to the analysis of independent samples $T$ test, 3D computer models are effective for better learning of the atomic models topic (see Table 2) in comparison with the traditional learning process with $2 \mathrm{D}$ representations involving pictures, figures, etc. in textbooks. This result is supported by other researches that suggest that $3 \mathrm{D}$ computer models provide higher academic achievement and learning performance in comparison with traditional approaches such as textbooks or 2D visualizations (Barab, Hay, Barnett, \& Keating, 2000; Daugherty, Li, \& Biocca, 2008; Dickey, 2005; Frederiksen, White, \& Gutwill, 1999; Gobert \& Pallant, 2004; Kim, 2006; Küçüközer, Korkusuz, Küçüközer, \& Yürütmezoğlu, 2009; Sanger \& Badger, 2001; Taylor, Barker, \& Jones, 2003; Young, 2004). With this result, it can be clearly stated that abstract issues such as science 3D computer models must be included in learning and teaching if possible. Also, the effect size (Cohen's $d$ ) when using 3D computer models was found to be 1.54. According to McMillan and Schumacher (2006), 3D models have large effects on learning about the atomic models topic (see in page 295 for evaluation criteria of Cohen's $d$ ).

Another result obtained from the study focused on students' mental model construction. According to one way MANOVA analysis, students in the TG had more correct and clear mental models in comparison with students in the CG. As seen in Table 3, their drawing scores and total scores are better than those of the students in the CG. This result is supported by some researchers (e.g., Barak \& Hussein-Farraj, 2013; Dalgarno, Hedberg, \& Harper, 2002; Gobert \& Pallant, 2004; Meheut, 2004; Urhahne et al., 2009; Wu \& Chiang, 2013; Wu \& Shah, 2004; Wu, Krajcik, \& Soloway, 2001) who have reported that 3D computer models and representations are better tools than 2D representations or physical materials. This is because they have the potential for building new, correct, and clear models or changing incomplete mental models in students' minds. Also, the eta-squared $\left(\square^{2}=.659\right)$ value in Table 4 shows that 3D computer models have large effects on students mental models. For evaluation of eta-squared, Leech, Barrett, and Morgan (2005, p.133) pointed out that .31 and higher values are indicators of large effects.

Lastly, the results of the ROT demonstrated that 3D computer models are effective in facilitating students' spatial ability. As seen in Table 5, the students in the TG increased their ROT scores after instruction. This result shows parallelism with many other studies (Potter \& Merwe, 2001; Alias, Black, \& Gray, 2002; Kwon, 2003; Lajoie, 2003; Woolf, Romoser, Bergeron, \& Fisher, 2003; Wu \& Shah, 2004; Kim, Yoon, Whang, Tversky, \& Morrison, 2007; Wang, Chang, \& Li, 2007; Williamson \& Jose, 2008) that report that 3D models and visualizations enhance students' spatial abilities. Also, Cohen's $d$ was found to be 1.16, thus showing that 3D models have large effects on students' spatial ability. According to Hartman et al. (2006), it may be possible to improve the spatial ability of students.

In this study, the effects of 3D computer models for learning the atomic models topic were investigated. The results show that these models are very effective tools for better learning, better 
mental model construction, and enhancing spatial ability. It can be clearly pointed out that for abstract concepts in science or in other disciplines, it is important to concretize them. Therefore, it is suggested that if the usage of these models is possible, they certainly must be included in the learning and teaching process. 


\section{References}

Acher, A., Arca, M., \& Sanmartí, N. (2007). Modeling as a teaching learning process for understanding materials: A case study in primary education. Science Education, 91, 398-418. http://dx.doi.org/10.1002/sce.20196

Akpan, J. P. (2001). Issues associated with inserting computer simulations into biology instruction: A review of the literature. Electronic Journal of Science Education, 5(3).

Alias, M., Black, T. R., \& Gray, D. E. (2002). Effect of instructions on spatial visualization ability in civil engineering students. International Educational Journal, 3(1), 1-12.

Ametller, J. \& Pinto, R. (2002). Students' reading of innovative images of energy at secondary school level. International Journal of Science Education, 24(3), 285-312. http://dx.doi.org/10.1080/09500690110078914

Barab, S. A., Hay, K. E., Barnett, M., \& Keating, T. (2000) Virtual solar system project: building understanding through model building. Journal of Research in Science Teaching, 37(7), 719-756. http://dx.doi.org/10.1002/1098-2736(200009)

Barak, M., Ashkar, T., \& Dori, Y. J. (2011). Learning science via animated movies: its effect on students thinking and motivation. Computers and Education, 56(3), 839 - 846. http://dx.doi.org/10.1016/j.compedu.2010.10.025

Barak, M. \& Hussein-Farraj, R. (2013). Integrating model-based learning and animations for enhancing students' understanding of proteins structure and function. Research in Science Education, 43(2). 619-636. http://dx.doi.org/10.1007/s11165-012-9280-7

Barnea, N. (2000). Teaching and learning about chemistry and modelling with a computer managed modelling system. In J. K. Gilbert, \& C. J. Boulter (Eds.), Developing Models

In Science Education. (pp.307-323). London, UK: Kluwer Academic Publishers.

Bekiroğlu Ogan, F. (2006). Pre-service physics teachers' knowledge of models and perceptions of modeling. Online Submission, Paper presented at the Annual GIREP Conference, (Amsterdam, The Netherlands). ERIC document number: 494979.

Black, A. A. J. (2005). Spatial ability and earth science conceptual understanding. Journal of Geoscience Education, 53(4), 402-414.

Bodner, G. M. (1976). Purdue Spatial Visualization Tests. Purdue Research Foundation: West Lafayette, IN. https://lphscadd.wikispaces.com/file/view/Purdue+Spatial+Test.pdf Accessed 06.11.2016

Bodner, G. M. \& Guay, R. B. (1997). The Purdue visualization of rotations test. The Chemical Educator, 2(4), 1-17. http://dx.doi.org/10.1007/s00897970138a

Buckley, B. C. \& Boulter, C. J. (2000). Investigating the role of representations and expressed models in building in mental models. In J. K. Gilbert, \& C. J. Boulter. (Eds.), Developing Models in Science Education (pp.119-136). London, UK: Kluwer Academic Publishers.

Chandler, P. \& Sweller, J. (1991). Cognitive load theory and the format of instruction. Cognition and Instruction, 8(4), 293-332. http://dx.doi.org/10.1207/s1532690xci0804_2

ChanLin, L. J. (2000). Attributes of animation for learning scientific knowledge. Journal of Instructional Psychology, 27(4), 228-238.

Chen, S. C., Hsiao, M. S., \& She, H. C. (2015). The effects of static versus dynamic 3D representations on 10th grade students' atomic orbital mental model construction: Evidence from eye movement behaviors. Computers in Human Behavior, 53, 169-180. http://dx.doi.org/10.1016/j.chb.2015.07.003

Coll, R. \& Treagust, D. F. (2003). Learners' mental models of metallic bonding: A cross-age study. Science Education, 87(5), 685-707. http://dx.doi.org/10.1002/sce.10059 
Dalgarno, B., Hedberg, J., \& Harper, B. (2002). The contribution of 3D environments to conceptual understanding. In O. J. McKerrow (Ed.), Winds of Change in the Sea of Learning: Proceedings of the 19th Annual Conference Australasian Society for Computers in Learning in Tertiary Education, (149-158). Auckland, New Zeland: UNITEC

Dickey, D. M. (2005). Three-dimensional virtual worlds and distance learning: Two case studies of active worlds as a medium for distance education. British Journal of Educational Technology, 36(3), 439-451. http://dx.doi.org/10.1111/j.1467-8535.2005.00477.x

Daugherty, T., Li, H., \& Biocca, F. (2008). Consumer learning and the effects of virtual experience relative to indirect and direct product experience. Psychology and Marketing, 25(7), 568-586. http://dx.doi.org/10.1002/mar.20225

Franco, C. \& Colinvaux, D. (2000). Grasping mental models. In J. K. Gilbert, \& C. J. Boulter (Eds.), Developing Models in Science Education (pp. 93-118). London, UK: Kluwer Academic Publishers.

Frederiksen, J. R., White, B. Y., \& Gutwill, J. (1999). Dynamic mental models in learning science: The importance of constructing derivational linkages among models. Journal of Research in Science Teaching, 36(7), 806-836. http://dx.doi.org/10.1002/(SICI)1098-2736(199909)

Gilbert, J. K. (2005). Visualization: A metacognitive skill in science and science education. In J. K. Gilbert (Ed.), Visualization in Science Education (pp. 9-27). Dordrecht: Springer.

Gilbert, J. K. \& Boulter, C. B. (1998). Learning science through models and modeling. In B. Fraser \& K. Tobin (Eds.), International Handbook of Science Education (pp. 53-66). Utrecht, the Netherlands: Kluwer Academic Publishers.

Gobert, J. (2000). A typology of models for plate tectonics: Inferential power and barriers to understanding. International Journal of Science Education, 22(9) 937 - 977. http://dx.doi.org/10.1080/095006900416857

Gobert, J. D. \& Pallant, A. (2004). Fostering students. Epistemologies of models via authentic model-based tasks. Journal of Science Education and Technology, 13(1), 7-22. http://dx.doi.org/10.1023/B:JOST.0000019635.70068.6f

Gobert, J. D., O’Dwyer, L., Horwitz, P., Buckley, B. C., Levy, S. T., \& Wilensky, U. (2011). Examining the relationship between students' understanding of the nature of models and conceptual learning in biology, physics, and chemistry. International Journal of Science Education, 33(5), 653 - 684. http://dx.doi.org/10.1080/09500691003720671

Gobert, J. D. \& Buckley, B. C. (2000). Introduction to model-based teaching and learning in science education. International Journal of Science Education, 22(9), 891 - 894. http://dx.doi.org/10.1080/095006900416839

Greca, I. M. \& Moreira, M. A. (2000). Mental models, conceptual models and modeling. International Journal of Science Education, 22(1), 1-11. http://dx.doi.org/10.1080/095006900289976

Habraken, C. L. (1996). Perceptions of chemistry: Why is the common perception of chemistry, the most visual of sciences, so distorted. Journal of Science Education and Technology, 5(3), 193201. http://dx.doi.org/10.1007/BF01575303

Halloun, I. (2007). Mediated modeling in science education. Science Education, 16, 653 - 697. http://dx.doi.org/10.1007/s11191-006-9004-3

Hartman, N. W., Connolly, P. E., Gilger, J.W., \& Bertoline, G. R. (2006). Developing a virtual reality-based spatial visualization assessment instrument. Presented at the American Society for Engineering Education Annual Conference, Chicago, IL.

Jara, C. A., Esquembre, F., Christian, W., Candelas, F. A., Torres, F., \& Dormido, S. (2012). A 
new 3D visualization Java framework based on physics principles. Computer Physics Communications, 183(2), 231-244. http://dx.doi.org/10.1016/j.cpc.2011.08.007

Justi, R. \& Gilbert, J. (2000). History and philosophy of science through models: Some challenges in the case of 'the atom'. International Journal of Science Education, 22(9), 993-1009. http://dx.doi.org/10.1080/095006900416875

Kim, M. S. \& Lee, W. C. (2013). Computer-enhanced multimodal modeling for supporting a learner generated topic. Research and Practice in Technology Enhanced Learning, 8(3), 363-384. Kim, P. (2006). Effects of 3D virtual reality of plate tectonics on fifth grade students' achievement and attitude toward science. Interactive Learning Environments. 14(1), 25-34. http://dx.doi.org/10.1080/10494820600697687

Kim, S., Yoon, M., Whang, S. M., Tversky, B., \& Morrison, J. B. (2007). The effect of animation on comprehension and interest. Journal of Computer Assisted Learning, 23, 260-270.

Koponen, I. T. (2007). Models and modeling in physics education: A critical re-analysis of philosophical underpinnings and suggestions for revisions. Science Education, 16(7), 751-773. http://dx.doi.org/10.1007/s11191-006-9000-7

Krell, M., Reinisch, B., \& Kruger, D. (2015). Analyzing students' understanding of models and modeling referring to the disciplines biology, chemistry, and physics. Research in Science Education, 45(3). http://dx.doi.org/10.1007/s11165-014-9427-9

Krell, M., Upmeier zu Belzen, A., \& Krüger, D. (2014). Students' levels of understanding models and modeling in Biology: Global or aspect-dependent? Research in Science Education, 44(1), 109132. http://dx.doi.org/10.1007/s11165-013-9365-y

Küçüközer, H., Korkusuz, M. E., Küçüközer, H. A., \& Yürütmezoğlu, K. (2009). The effect of 3D computer modeling and observation-based instruction on the conceptual change regarding basic concepts of astronomy in elementary school students. Astronomy Education Review, 8(1). http://dx.doi.org/10.3847/AER2009006

Kwon, O. N. (2003). Fostering spatial visualization ability through web-based virtual-reality program and paper-based program. Lecture Notes in Computer Science, 27(13), 701-706.

Lajoie, S. P. (2003). Individual differences in spatial ability: Developing technologies to increase strategy awareness and skills. Educational Psychologist, 38(2), 115-125.

Leech, N. L., Barrett, K. C., \& Morgan, G. A. (2005). SPSS for intermediate statistics: Use and interpretation. (Second Edition). London: Lawrence Erlbaum Associates, Inc.

Lohman, F. (1993). Spatial ability and G. Paper presented at the first Spearman Seminar, University of Plymouth, July 21.

http://citeseerx.ist.psu.edu/viewdoc/download;jsessionid=560D26B4175B6E6A0ADA9FB8CA6

00DBD?doi=10.1.1.111.7385\&rep=rep1\&type=pdf Accessed 15.11.06

Mayer, R. E. (2003). The promise of multimedia learning: Using the same instructional design methods across different media. Learning and Instruction, 13(2), 125-139. http://dx.doi.org/10.1016/S0959-4752(02)00016-6

Mayer, R. E. \& Moreno, R. (2002). Aids to computer-based multimedia learning. Learning and Instruction, 12(1), 107-119. http://dx.doi.org/10.1016/S0959-4752(01)00018-4

Mayer, R. E. \& Moreno, R. (2003). Nine ways to reduce cognitive load in multimedia learning. Educational Psychologist, 38(1), 43 - 52. http://dx.doi.org/10.1207/S15326985EP3801_6

McMillan, J. H. \& Schumacher, S. (2006). Research in Education: Evidence-Based Inquiry. (Sixth Edition). Boston, MA: Allyn and Bacon.

Meheut, M. (2004). Designing and validating two teaching-learning sequences about particle models. International Journal of Science Education, 26(5), 605-618. 
http://dx.doi.org/10.1080/09500690310001614726

Moreno, R. \& Valdez, A. (2005). Cognitive load and learning effects of having students organize pictures and words in multimedia environment: The role of student interactivity and feedback. Educational technology Research and Development, 53(3), 35-45.

http://dx.doi.org/10.1007/BF02504796

Nakiboglu, C. (2003). Instructional misconceptions of Turkish prospective chemistry teachers about atomic orbitals and hybridization. Chemistry Education Research and Practice, 4(2), 171188. http://dx.doi.org/10.1039/B2RP90043B

Orde, B. J. (1997). Drawing as visual-perceptual and spatial ability training. http://eric.ed.gov/ERICDocs/data/ericdocs2sql/content_storage_01/0000019b/80/16/c4/7b.pdf Accessed 14.11.06

Paas, F., Tuovinen, J. E., Tabbers, H., \& Van Gerven, P. W. M. (2003). Cognitive load measurement as a means to advance cognitive load theory. Educational Psychologist, 38(1), 6371 http://dx.doi.org/10.1207/S15326985EP3801_8

Patrick, M. D., Carter, G., \& Wiebe, E. N. (2005). Visual representations of DNA replication: Middle grades students' perceptions and interpretations. Journal of Science Education and Technology, 14(3), 353-365. http://dx.doi.org/10.1007/s10956-005-7200-6

Potter, C. \& Merwe, E. (2001). Spatial ability, visual imagery and academic performance in engineering graphics. In Proceedings of the International Conference on Engineering Education. Oslo/Bergen, Norway.

Rutten, N., Van Joolingen, W. R., \& van der Veen, J. T. (2012). The learning effects of computer simulations in science education. Computers \& Education, 58(1), 136-153.

http://dx.doi.org/10.1016/j.compedu.2011.07.017

Sanger, M. J. \& Badger, S. M. (2001). Using computer-based visualization strategies to improve students' understanding of molecular polarity and miscibility. Journal of Chemical Education, 78(10), 1412-1416. http://dx.doi.org/10.1021/ed078p1412

Taber, K. S. (2001). Building the structural concepts of chemistry: Some considerations from educational research. Chemistry Education: Research and Practice in Europe, 2(2), 123-158. http://dx.doi.org/10.1039/B1RP90014E

Taylor, I., Barker, M., \& Jones, A. (2003). Promoting mental model building in astronomy education. International Journal of Science Education, 25(10), 1205-1225.

http://dx.doi.org/10.1080/0950069022000017270a

Tsaparlis, G. (1997). Atomic orbitals, molecular orbitals and related concepts: Conceptual difficulties among chemistry students. Research in Science Education, 27(2), 271-287. http://dx.doi.org/10.1007/BF02461321

Urhahne, D., Nick, S., \& Schanze, S. (2009). The effect of three-dimensional simulations on the understanding of chemical structures and their properties. Research in Science Education, 39(4), 495-513. http://dx.doi.org/10.1007/s11165-008-9091-z

Valanides, N. \& Angeli, C. (2008). Learning and teaching about scientific models with a computer modeling tool. Computers in Human Behavior, 24(2), 220-233. http://dx.doi.org/10.1016/j.chb.2007.01.005

Vasniadou, S. \& Brewer, W. (1992). Mental models of the earth: a study of conceptual change in childhood. Cognitive Psychology, 24(4), 535-585. http://dx.doi.org/10.1016/00100285(92)90018-W

Wang, H. C., Chang, C. Y., \& Li, T. Y. (2007). The comparative efficacy of 2D- versus 3D-based media design for influencing spatial visualization skills. Computers in Human Behavior, 23, 1943-

1957. 
Williamson, V. M. \& Jose, T. J. (2008). The effects of a two-year molecular visualization experience on teachers' attitudes, content knowledge, and spatial ability. Journal of Chemical Education, 85(5), 718-723. http://dx.doi.org/10.1021/ed085p718

Woolf, B., Romoser, M., Bergeron, D., \& Fisher, D. (2003). Tutoring three-dimensional visual skills: Dynamic adaptation to cognitive level. In Proceedings of the Eleventh International Conference on Artificial Intelligence in Education. Sydney, Australia.

Wu, C. F. \& Chiang, M. C. (2013). Effectiveness of applying 2D static depictions and 3D animations to orthographic views learning in graphical course. Computers \& Education, 63, 2842. http://dx.doi.org/10.1016/j.compedu.2012.11.012

Wu, H. K., Krajcik, J. S., \& Soloway, E. (2001). Promoting understanding of chemical representations: students' use of a visualization tool in the classroom. Journal of Research in Science Teaching, 38(7), 821-842. http://dx.doi.org/10.1002/tea.1033

$\mathrm{Wu}, \mathrm{K} . \&$ Shah, P. (2004). Exploring visuospatial thinking in chemistry learning. Science Education, 88(3), 465-492. http://dx.doi.org/10.1002/sce.10126

Young, Y. Y. (2004). A learner-centered approach for training science teachers through virtual reality and $3 D$ visualization technologies: practical experience for sharing. Conference Paper presented at The Fourth International Forum on Education Reform (September, 2004).

http://citeseerx.ist.psu.edu/viewdoc/download?doi=10.1.1.129.4865\&rep=rep1\&type=pdf Accessed 01.11.2016

Zhang, B. H., Liu, X., \& Krajcik, S. (2006). Expert models and modeling processes associated with a computer-modeling tool. Science Education, 90(4), 579-604. http://dx.doi.org/10.1002/sce.20129 